\title{
AUSTRALIAN RULES FOOTBALL CHEER SQUADS OF THE EIGHTIES: A CASE STUDY OF THE WEST PERTH CHEER SQUAD 1984-1986
}

\author{
Kieran James \\ University of the West of Scotland, Paisley, Scotland
}

\begin{abstract}
Background. In this article I review key studies in the academic literature on football (soccer) hooliganism in the UK and around the world. I apply Armstrong's anthropological approach to our 15-20 member West Perth unofficial cheer squad (hard-core supporter group) of 1984-1986 (Australian Rules football's WAFL competition).

Method. This is an ethnographic study of the West Perth cheer squad 1984-86 told from the viewpoint of the author who was co-founder and co-leader of this group. It is both strength and weakness of the research data that the author was an active participant in the events rather than a researcher performing typical ethnographic research as a non-participant.

Results. I find that the anthropological approach is able to explain many aspects of our cheer squad's culture and members' behaviours including the quick disintegration of the cheer squad early in the 1986 season without anyone officially ending it. However, our group members did not adjust their commitment downwards during the cheer squad's years of action; most members attended all home-and-away matches during May 1984-March 1986. This research also shows the diffusion of Australian Rules football supporter culture from Melbourne to Adelaide and from these two cities to Perth, to a lesser extent, and the impact of TV news reports of British football hooliganism on our group's style and macho posturing.

Conclusion. Detailed long-term ethnographic studies of individual football (soccer) hooligan firms and Australian Rules' cheer squads are the most vital type of new research.
\end{abstract}

Keywords: football hooliganism, neo-tribes, Perth history, sports history, Western Australian football.

\section{INTRODUCTION}

$\checkmark T^{2}$ eneral Introduction. "By channelling the competitive hostility outwards towards the tribe on the other side of the [usually metaphorical] hill, social bonds within one's own group are reaffirmed and maintained" (Marsh, 1978, p. 50).

In this article I review key studies in the academic literature on football hooliganism in the UK and around the world. The academic theories can be divided into: the early dominant "figurational" or "process-sociological" approach of Dunning and colleagues; the "anthropological" approach of Armstrong and Harris (with its focus on fluid "postmodern" "neo-tribes"); the post-modern approach of Giulianotti; the Marxist approach of Taylor, Clarke, and Hargreaves; the "ethogenic" approach of Marsh; the "psychological reversal theory" approach of Kerr; and the historically sensitive / historical approaches of King and Robson. I apply Armstrong's (1998) anthropological approach to our 15-20 member West Perth cheer squad (hardcore supporter group) of 1984-1986 (Australian Rules football's WAFL competition). I find that the anthropological approach is able to explain many aspects of our cheer squad's culture and members' behaviours including the quick disintegration of the cheer squad early in the 1986 season without anyone officially ending it. However, our group members 
did not adjust their commitment downwards during the cheer squad's years of action; most members attended all home-and-away matches during May 1984-March 1986.

West Perth has been a foundation member of the Perth-based Western Australian Football League (WAFL) competition since 1885. However, the WAFL was reduced to second-tier status when Perth-based West Coast Eagles entered the expanded Victorian Football League (VFL) (now Australian Football League (AFL)) in time for the 1987 season (Devaney, n.d.). The VFL/AFL now operates as a de facto national premier league (first division). As in American professional sport, there is no promotion to or relegation from the VFL/ AFL to the various second-tier leagues. During the twentieth century, up to 1982 , the VFL/AFL was based solely in the state of Victoria (and 11 of its 12 clubs were then based in the city of Melbourne).

A cheer squad (an Australian Rules football term) is a semi-organized group of hard-core supporters (comprising typically but not always a male teenager majority) which sits in the same strategic place at home matches and which supports the team through chants, songs, flags, and banners. It may attend some or all away matches, and usually sits in a humble location at away venues (near the entrance which is closest to the train station for example) and rarely tries to take over the home cheer squad's territory. Australian Rules football cheer squads should not be confused with the cheer squads of American Football which are, obviously, completely different. The dominant culture at Melbourne- and Adelaide-based cheer squads, since the formation of the first cheer squad at VFL/ AFL club Richmond in 1959 (Critchley, 2010), has included an important fraternal ethos among rival cheer squad members especially away from the grounds. The cheer squads took on some of the "illusion of violence" (Marsh, 1978) or tough-guy posturing from British and European hooligans and ultras. However, this was more in terms of style and posturing; cheer squads rarely sought out or engaged in actual violent actions. Another influence arguably was the ultras groups formed by Australian football (soccer) supporters from European ethnic immigrant backgrounds including those connected to clubs such as Melbourne Croatia; Sydney Croatia; South Melbourne Hellas; and Sydney Olympic (James \& Walsh, 2017).

The aim of this article is to apply Gary Armstrong's theory of fluid "post-modern" "neo-tribes" (Armstrong, 1998) to our West Perth cheer squad 1984-1986 and draw appropriate theoretically-informed conclusions from this application. We also use Peter Marsh's concept of the "illusion of violence" (Marsh, 1978) which suggests that, in order to gain and demonstrate control over territory and resources, rival groups engage in symbolic behaviours (advances and retreats) which more often than not involve only mild violence or no violence at all. If group selfrespect, integrity, and territorial control can be achieved without actual violence then, as the theory goes, so much the better.

Motivation. It is important to study the behaviours and cultures of Australian Rules football hard-core supporters and cheer squads as this has been an under-researched area. Much of what we do know to date comes largely from personal memories and anecdotes and from occasional comments and digressions in Australian Rules football history books of various kinds (see, for example, Muyt, 2006).

Background. The three largest population centres where Australian Rules football is the most popular winter sport are Melbourne, Adelaide, and Perth. Traditionally the Melbourne-based VFL/ AFL competition had and has the best football, the largest crowds, and the most passionate supporters compared to the local competitions based in the other two cities (the SANFL in Adelaide and the WAFL in Perth). Football supporter culture has typically diffused from Melbourne to Adelaide (654 kilometres to the west) and, only to a lesser extent and at a slower rate, from these two centres to Perth. Slow diffusion to Perth is largely due to distance: Perth is located far away on the country's west coast 2.131 kilometres from Adelaide and 2.721 kilometres from Melbourne. Until recent years poorer people rarely travelled from Perth to Melbourne but travel from Adelaide to Melbourne was much more common due to the fact that it was within easy driving distance. As a result seventies and eighties football supporter culture diffused faster and to a greater extent from Melbourne to Adelaide than from these two cities to Perth.

In the peak cheer squad years of the VFL/AFL in the seventies and eighties, when the then it was a Melbourne suburban competition plus Geelong, cheer squad members from various clubs would catch up with each other after games at Flinders Street Station and shout across station platforms the scores from their respective grounds. There was 
also a place called Classic Cafe in Melbourne citycentre where cheer squad members congregated and interacted on Saturday nights after the regular Saturday afternoon home-and-away games (Muyt, 2006). If anything, cheer squad members have been less violent than ordinary supporters of Australian Rules' clubs. A distinction has been made between the inner and outer cheer squad at Collingwood (Muyt, 2006) where the inner cheer squad was the approved membership that adhered to fraternal cheer squad ethics whereas the outer cheer squad was the hooligan element not under the restraining influence of cheer squad leaders. However, I argue that, despite this, the "illusion of violence" has always been important, to some extent, for Melbourne- and Adelaide-based cheer squads.

The fraternal Melbourne- and Adelaide-based cheer squad culture merged with the outwardly more aggressive English football (soccer) hooligan culture, which regularly appeared on Australian TV news reports, to create the ethos of groups such as our West Perth cheer squad. Growing up as teenagers in Australia in the eighties we all saw the TV news reports of football hooligan violence coming from the UK and, being eager to prove our credentials, we adopted some of their tough-guy posturing or "illusion of violence" (Marsh, 1978); the influence was there definitely at the subconscious level if not at the conscious level. So to say that Australian Rules football crowds and football (soccer) crowds are unrelated topics is simply nonsense. However, we never initiated violence and we were only once seriously threatened by it (at Bassendean Oval). The events of that particular day will be presented and analysed in the Results and Discussion sections of this article respectively.

As mentioned, the Australian Rules football cheer squad culture, coming out of Melbourne and to a lesser extent Adelaide, involved a fraternal ethics between rival cheer squads, especially away from the grounds, and that was a countervailing force, and probably our dominant influence. Our posturing was macho and our songs and chants were loud and insulting but we were not interested in initiating violence. The leading cheer squads in WAFL (Perth) football in 1984-85 were Perth FC, Claremont, Subiaco, West Perth, and East Perth, probably in that order or with West Perth as third. None of the remaining three WAFL clubs had semi-organized cheer squads of any type as far as key people were aware. Perth and Claremont might have had 20-30 people on a good day, and our West Perth group had a stable core of 15-20. By the second half of our existence we had around 15 large red-and-blue flags or one flag per core member.

West Perth in fact had three cheer squads during the 1984-1986 period: (a) Fat Pam's cheer squad, which disbanded at the end of the 1983 season but continued to still make the banners the players ran through before the game; (b) our unofficial group situated behind the northern-end goals, which replaced Fat Pam's group which had formerly used that location; and (c) the Grandstand Falcons, a group of older guys then in their twenties who sat at the top of the Leederville Oval grandstand and sang songs (but had no flags or floggers). This shows the passion and commitment of grassroots supporters for many of the Western Australian Football League (WAFL) clubs during the eighties when average match attendances for home-andaway fixtures were around seven to eight thousand.

At one Subiaco Oval (neutral-venue) game, our cheer squad sat in front of the Grandstand Falcons with a third section of seats in front of our cheer squad reserved for our flags and banners. (Our group never took floggers to away games but instead we stored them in the West Perth FC club facilities at Leederville Oval.). Altogether there would have been over 50 people there that day across both groups combined. The noise the combined group made under the grandstand roof, on the second- (middle-) tier of the three-tier stand behind the Fremantle-end goals, was magnificent when magnified by the echoes. We sang the Grandstand Falcons' powerful song "This Time, We'll Get It Right" about England's 1982 World Cup hopes (with England changed to West Perth and the "white" dropped from "red, white, and blue"). This song summed up perfectly people's emotions at the time because it had been a decade since West Perth had last played in a grand-final (Atkinson, 2008) and hopes had been dashed on many occasions. In hindsight, this was our cheer squad's greatest day.

The largest and best organized cheer squad was Perth Football Club's under the leadership of a very warm, cheerful, and sophisticated "metrosexual" guy with blond-rinse hair called Nick. Nick brought the disciplined and fraternal Melbournebased (VFL/AFL) cheer squad ethics over to the

\footnotetext{
1 See: https://www.youtube.com/watch?v=2w3 PZh0IR4 [accessed 14 September 2017].
} 
Perth Football Club. This cheer squad had existed since at least around 1981. To this day the wooden bench seats behind the northern- or city-end goals at Lathlain Park, Perth's home ground, are painted red-and-black, a permanent reminder of the days (and years) when Nick's passionate cheer squad occupied those benches.

The Claremont cheer squad was probably similarly influenced by the Melbourne-based cheer squads since one of its core members wore a Melbourne-style duffel coat with club name and favourite player name and number (Peter 15 Jamieson) emblazoned on the back in big iron-on lettering. The duffel-coat culture never caught on in Perth as, unlike in Adelaide, few school-aged Perthbased supporters then made trips to Melbourne or Adelaide to watch VFL/AFL or SANFL games, and the only places to see the duffel-coat culture were Melbourne and Adelaide. Furthermore, the Perth winter is milder and too hot for duffel coats.

These duffel coats were excellent for standing on the terraces in the rain on Saturday afternoons in Melbourne because the rain-soaked coats could simply be left out to dry and would be wearable one week later. It was common in 1982 to see these duffel-coats with team and player names and pin-on player badges being worn on the streets by teenagers on weekdays in the city-centre. However, by 1986 , the coats were mostly only being worn at games while by the nineties they had disappeared from the stadiums as well. All-seater stadiums with covered roof sections had made them redundant. By the late-nineties the VFL/AFL had abandoned scheduling fixtures at most traditional suburban home grounds of the clubs with their uncovered concrete terracing; and most games were being scheduled at the larger, all-seater stadiums namely the Melbourne Cricket Ground (MCG); VFL Park; and, from 2000, the Docklands' Stadium.

Literature review. Several authors touch on the fascinating intersection between football hooliganism and punk rock music. West Ham United Inter-City Firm (ICF) leader Cass Pennant (Pennant, 2003, chap. 6) considers the case of punk rock bands Sham 69 and Cockney Rejects whose East London identifications are well known. These East London identifications made sense within the punk rock scene which has always had a sociologically informed emphasis upon place which can be traced back to the Sex Pistols and the SEX shop run by Westwood and McLaren at 430 The King's Road, Chelsea (Bestley, 2011;
Savage, 2005). Local East London historian John G. Bennett (who led a "Jack the Ripper" guided tour I attended in Whitechapel on 10 June 2010) cites Sham 69's song "George Davis is Innocent" from the band's debut album 1978's Tell the Truth: "They're never gonna leave you alone / They're never gonna leave you alone / You know where you bloody live / East London is your home!"2 As Sham 69 was in fact from Hersham in outer southwest London, this song suggests that East London had by 1978 become a romanticized spiritual locality uncontainable by its actual geographic boundaries. However, despite song lyrics such as these, the close links between West Ham United's ICF and band members of The Business, Cock Sparrer, Cockney Rejects, and Sham 69 are less well documented. A famous picture shows the Cock Sparrer band members proudly posing inside the gates at West Ham's Upton Park stadium. As Pennant (2003, chap. 6) writes, this known link between certain East London punk bands and West Ham's ICF resulted in Cockney Rejects' concerts in the Midlands and north of England becoming sites of football-related violence. ${ }^{3}$ It was footballrelated violence because the band members were attacked because of their identification with and support for West Ham United and the ICF and not for any other reason.

Moving on to today, Cockney Rejects released a very moving new single and video-clip on 11 April 2016 called "Goodbye Upton Park" about West Ham's permanent move from the Boleyn Ground / Upton Park to the London Olympic Stadium. ${ }^{4}$ It can be argued that this video-clip goes beyond a simple farewell to a veiled protest at the corporatization of football and the destruction and sale of valuable personal and community memories.

This article also considers why hooliganism of the British variety never caught on in Australian Rules or even in Australian football (soccer) and is unlikely to do so in the future especially with regards to the former. This is a complex question. It is important to point out that British football hooliganism, like British punk rock, was a unique product of time and place. Marsh (1978, p. 90)

\footnotetext{
2 Sham 69 lyrics as cited in Bennett (2009, p. 34).

3 See also interview with Cockney Rejects' frontman Jeff Geggus aka Jeff Turner aka "Stinky" Turner at: https://www.youtube.com/watch?v=9nKdqO279kI [accessed 11 January 2017].

${ }^{4}$ See: https://www.youtube.com/watch?v=HAsyGA5a-g [accessed 5 January 2017].
} 
explains as follows: "aggro always reflects, in the particular form it takes on, the social forces of a given era". Sociologically football hooliganism belonged to the seventies and eighties, the time when the post-war "consensus" between the two major political parties had broken down; unemployment was rising appreciably for the first time since the end of World War II; the Labour Party under the late James Callaghan faced the indignity of enforced civil service cuts under an International Monetary Fund (IMF) austerity package; and (later) Mrs. Thatcher's economic rationalism and anti-trade union stance rendered life much more difficult for what remained of the working-class (Savage, 2005, p. 480). Even in a different era in the UK (or an "alternative history" using a concept of Slavoj Žižek) hooliganism may not have happened or possibly would not have happened.

Dunning et al. (2002) outline the major "popular" theories of hooliganism put forward by non-academics in the media and politics. After this they outline the main academic approaches used by the academic researchers. The popular arguments tend to be difficult to shed light on through empirical research and hence difficult to conclusively accept or reject. Another point to note, highlighted in Dunning et al.'s (2002) review chapter, is that some of the popular theories contradict each other. For example, the theory that hooliganism is due to unemployment appears to contradict the theory that hooliganism is due to affluence. The popular theories are as follows: football hooliganism is caused by: "[1] excessive alcohol consumption; [2] violent incidents on the field of play or biased and incompetent refereeing; [3] unemployment; [4] affluence; and [5] 'permissiveness" (Dunning et al., 2002, p. 11).

The academic theories can be divided into: the early-dominant "figurational" or "processsociological" approach of Dunning et al. (Dunning, 1999; Dunning et al., 1991); the "anthropological" approach of Armstrong and Harris (Armstrong, 1998; Armstrong \& Harris, 1991); the post-modern approach of Giulianotti; the Marxist approach of Taylor, Clarke, and Hargreaves; the "ethogenic" approach of Marsh (1978); the "psychological reversal theory" approach of Kerr; and the historically sensitive / historical approaches of King and Robson (cited in Dunning et al., 2002, p. 13). We rely predominantly on Armstrong's anthropological approach while hoping to gain insight from all of the relevant theories, none of which should be completely cast aside.

Dunning (1999) theorizes that football violence occurs around a given city or region's "faultlines" which might be class-based (as in England); religion-based (as in Glasgow); ethnicity-based (as in South African soccer and Australia's former National Soccer League (NSL) (1977-2004)); or regional-based; or city-versus-country-based.

Interestingly, Pave Jusup and Kova of Melbourne Croatia Fans (the current ultras group at ex-NSL club Melbourne Knights) distinguish Melbourne Knights' "political" rivalries with Yugoslav communist clubs such as Footscray JUST and Serbian clubs such as Springvale White Eagles with the (non-political) "football" rivalries with old NSL clubs such as the Italian community's Adelaide City Juventus and the Greek community's South Melbourne Hellas (source: group interview with the author, Sunshine North, 11 January 2011). Pave argues that the rivalries with Adelaide City and South Melbourne are "non-political" since they resulted simply from on-field events such as Melbourne Knights' grand-final defeats at the hands of these two clubs rather than to ItalianCroatian or Greek-Croatian issues.

Dunning (1999) theorizes that working-class people identify with their football team to the extent that they feel pride and self-respect when the team does well and loss of pride and loss of self-respect when the team does badly. Regarding Australia's ethnic soccer clubs in the former NSL (which was replaced by the A-League in 2004-05), Lynch and Veal (1996, p. 259) write that: "Nationalistic loyalty also played a part: a club victory could take on the stature of a 'victory' for a homeland, just as a defeat was also somewhat about loss of national face". The strength of these feelings of pride / loss of pride is based on the degree of the person's identification with the team and with the district and the number of interests that she / he has outside of football. For the person with strong identification with the district and few outside interests, the pride or loss of pride felt when the team does well or badly is at the maximum level. West Ham United ICF lead man Bill Gardner (Gardiner, 2006) has said that the West Ham fans of the seventies and eighties were dispirited and felt a loss of pride because of the first XI's poor showings and lack of effort; this inspired the ICF to become the strongest football hooligan firm in the country. 
Next I move on to review the ethnographic academic research on hooliganism that began in the nineties with two landmark $\mathrm{PhD}$ theses, one in the UK by Gary Armstrong on Sheffield United's Blades hooligan firm (later published as Football Hooligans - Knowing the Score) and one in Australia by John Hughson on Sydney United's Bad Blue Boys NSL firm from the early-nineties. Subsequent articles by Hughson (1997a, 1997b, 1999, 2000, 2002) synthesize key findings of these two studies and relate some of Armstrong's key findings to the unique context of south-west Sydney's Bad Blue Boys (BBB), a group of Croatian-Australian teenagers who are, or perhaps were, hard-core supporters of the former NSL's Sydney Croatia club (which was renamed Sydney United in the nineties). It should be pointed out that these "anthropological" authors have been criticized on a number of grounds by other academic researchers (see, for example, Dunning et al., 2002). Armstrong (1998) has also criticized the early-dominant Leicester University School approach of Dunning and Williams.

Using the anthropological approach, Armstrong (1998) focuses on the disorganized nature of Sheffield United's Blades' firm and the fluidity of group membership. People come to and go from the Blades according to the needs of their lives at particular stages and no-one is ever "bound" to the Blades in any sense. People connected with the Blades acknowledge that hooliganism is an acquired taste and a profession at the edge of even hard-core fan support (Allan, 1989, p. 109). Armstrong (1998, p. 306) talks in terms of fluid "post-modern" "neo-tribes" and this terminology and its associated logic is taken up by Hughson in his ethnographic study of Sydney United's BBB.

Armstrong (1998) points out that firm allegiance is bounded and held in tight check. It is generally subordinated to ordinary relationships so that a Blades member would put to one side (or suppress) his / her hostility towards Sheffield Wednesday's "Owls" hooligans when relating in the normal way to friends, family members, and work colleagues. When Blades and Owls meet outside of match days the context is often ambiguous and people have to determine whether this is a "football context" where fighting is justified or not. When groups of Blades or Owls invade each other's pubs on London Road or West Street on a Friday night this is a football context whereas if Blades or Owls are socializing with women or with non-hooligan mates this is not a football context and so football-related violence is unacceptable.

Significantly, neither Blades nor Owls members meet frequently outside of football seasons (Armstrong, 1998, p. 268) because such meetings are ambiguous and hard to interpret as being football-related. Armstrong (1998, p. 268, emphasis original) writes as follows: [T] he raison d'être of the Blades was a football match, and a collective identity more or less died outside the football season, to be resurrected at the early August pre-season friendly games". On the other hand, it was possible for the Blades' collective identity to assert itself as dominant at gatherings outside of the football season such as a marriage celebration and a $30^{\text {th }}$-birthday celebration (Armstrong, 1998, pp. 269-270). Armstrong (1998, p. 270, emphasis original) states as follows: "Blade identity could therefore be automatically sustained away from the club and the match in other contexts that did not need a game of football [nor even the football season]".

Likewise, our West Perth cheer squad 19841986 (which sat behind the northern-end goals at West Perth's Leederville Oval and had around 1520 core members) met only once outside of football seasons - when Mike C., his younger brother Pete C., and I arranged to attend a one-day domestic cricket match at the WACA Ground. However, this was early in the cricket season (October or November) and the planning to meet took place at the last West Perth football game. In effect, this cricket match can be seen as a special one-day extension of the football season.

I now move on to discuss the "phases of hooliganism" theory as outlined in various places by Dunning and his Leicester University School. In the first phase, Dunning argues that violence mostly involved attacks on players and officials. It emerged from uncontrolled passions inspired directly by events on the field (Duke \& Slepička, 2002 , p. 60). This type of violence, referred to as "spectator disorderliness" by Roversi and Balestri (2002, p. 131), was not pre-planned. Duke and Slepička (2002, p. 52) explain that, in the pre-1946 or pre-communist era in the then Czechoslovakia:

"most of the crowd incidents ... were match related. Attacks on players and officials were characteristic of football spectator behaviour in the first Czechoslovak republic. Battles between groups of rival fans were not common, and there were no reported examples of the police coming under attack from gangs of fans". 
After the sixties "core football hooliganism" emerged in England which was rival gangs of super-fighters intent on fighting each other; in this phase the violence was often pre-meditated (Duke \& Slepička, 2002, p. 60). Through a process of diffusion, the English hooligan style aka the "English disease" diffused firstly to Western Europe in the seventies (Duke \& Crolley, 1996; Duke \& Slepička, 2002, p. 53) and later to communist or post-communist Eastern Europe. In the then Czechoslovakia, Dunning's second phase did not diffuse into the local setting until the mid-eighties (Duke \& Slepička, 2002, p. 60). The reason for the slow diffusion was "because of the relative isolation, restricted media coverage and rigorous repression under the communist regimes" (ibid., p. 60).

Duke and Slepička (2002) also allege that communist rule was associated, especially in its early years, with a reduction in all types of football violence. Spectator disorderliness decreased from its pre-communist levels and core hooliganism started much later and on a much lesser scale in the then Czechoslovakia compared to Western Europe. These authors attribute this to mass communist repression being effective in its early years but declining in its effectiveness by the eighties. It was not until the nineties that the new Czech Republic experienced its first cases of fan attacks upon police. Overall, Duke and Slepička (2002, p. 60) conclude that: "developments in the Czech Republic occurred later both in terms of the degree of organisation involved and the nature of the violence". This suggests that hooliganism diffuses at different speeds and to various extents to different regions and that some types of hooliganism are never diffused to some locations.

The Leicester University School's "phases" theory has been developed beyond that discussed in Duke and Slepička (2002) and explained in the previous paragraph. According to Dunning et al. (2002, p. 102), there were three phases of English soccer hooliganism in the post-war era. Firstly, in the fifties and sixties, "the conflicts on the terraces were interpersonal in character, took place mainly in the soccer grounds and on trains, and were for the most part directly related to the outcome of the match" (ibid., p. 102). Secondly, during the seventies, "football hooliganism was transformed into mass violence, which took place outside as well as inside the grounds and took the form of violent collective, or crowd, behaviour" (ibid., p. 102). During the last phase, since the eighties, "hooligan violence has been displaced from the grounds and diffused into city centres, suburbs and even further away from the ground itself and may take place independently of the outcome of the game, for fighting can begin before or after the game and can continue for a long time" (ibid., p. 102). The Leicester University School's "phases" categorization fails to take into account the alleged general hardening up of attitudes and behaviours in England which took place around 1974. Pennant and Silvester (2004) nominate 1974 as a key dividing year.

Armstrong (1998) ends his book by describing how Blades would sometimes in 1997 watch games at pubs close to the Bramall Lane ground partly as a protest against rising ticket prices. This is the beginning of, in Armstrong's words, "post-fan" behaviour. Armstrong's data ends in 1997 and so we do not how the Blades are functioning in the new millennium. Generally rising season ticket prices and the rising cost of train travel have meant that the demographic of football support has changed while improved policing methods are a further factor in creating disinterest in hooliganism.

"Core football hooliganism" (Dunning's term) has never been diffused successfully to Australia. There has been occasional Australian Rules' crowd violence of the "first phase" type referred to as "spectator disorderliness". This type involves isolated attacks on players and umpires emerging out of passions generated by the match itself. Most Australian Rules' reference books suggest that these incidents occurred more frequently in the sport's early years prior to World War I (Critchley, 2010). They do not appear to have grown more serious or frequent as the years have passed. As with North American professional sport crowds (Young, 2002), I argue that Australian Rules' crowds have not moved beyond the Leicester University School's "spectator disorderliness" phase and are unlikely to do so in the future given top-level Australian sports' increasing mimicking of the North American professional sport culture and the ideological re-positioning of the supporter as consumer.

Armstrong (1998) produces very interesting data in the form of a list compiled in April 1987 of 190 Blades with ages, occupations, and criminal record (if any) listed. He classifies these into subgangs and, as with our West Perth cheer squad (see Appendix for a list of West Perth cheer squad 
sub-gangs), some sub-gangs might have had as few as two or three members. Larger sub-gangs which were part of the Blades included Old Lads; Drug Squad; Suicide Squad; Max's Coach Blades; Villagers; and Rotherham Blades. These last two groups were the most obviously separate since their outside-of-Sheffield locations influenced how they viewed themselves, other Blades, and other firms, and also influenced their willingness to fight. They felt that certain City Blades were too close to certain City Owls and hence sometimes not willing to confront them. Clearly, the out-of-Sheffield Blades were more idealistic and less pragmatic than the City Blades. Armstrong also recounts the interesting and ironic case of Rotherham Blades fighting Rotherham Owls or outside supporters and, in doing so, defending the honour of a city they do not live in. The present article follows Armstrong's (1998) example. Appendix lists our West Perth cheer squad's sub-gangs and the members belonging to each.

Armstrong (1998) emphasizes the casual nature of group ties and the recognition that a person was not morally bound to the firm in any way if he / she decided to give up football or give up hooliganism as part of a natural evolution within his / her own personal life. Some people might "come out of retirement" for big matches against the Owls or if a confrontation came to them. They would often continue to go to games and London Road Friday night pub sessions but sit with non-hooligan mates or sit with Blades but not leave the pub (bar) to meet a challenge outside (Armstrong, 1998, p. 266).

Generally, Hughson's research of BBB supports this. He tells the humorous example of one Croatian-Australian hooligan with his girlfriend being ridiculed by the group for his love interest to the extent that over time he, and others in similar positions, disappeared to the fringes of the group or left it entirely. This hooligan was taunted by the Croatian word for "slippers" which signifies domestic bliss and a certain married lifestyle.

Critique of Armstrong (1998). Armstrong (1998) only discusses leaving hooliganism in terms of changing life-stages without also referring to people's changed position in relation to capital. $\mathrm{He}$ sometimes uses the word "capitalism" in mocking inverted quotation marks (see, for example, p. 311) as if to question either the concept or its relevance or both. At the same time, when he talks about rising ticket prices and the social control of supporters this is within the context, which he does not acknowledge, of professional football moving to a higher stage of capitalism where supporters are re-classified as "consumers". Armstrong (1998) also rejects the neo-Marxist Althusserian concept of Ideological State Apparatuses and the related idea that schools, police, courts, politicians, and media all operate, in the last instance, to further and safeguard the interests of capital (Althusser, 2001/1971). However, the physical rebuilding of Sheffield United's Bramall Lane ground indeed shows the ideological re-interpellation of supporters as consumers whereby the consumers' average spend becomes more important than their degree of passionate commitment. In fact, the traditional supporters' passionate commitment is turned against them by the ruling-class of football so that that passion is now viewed as a liability which must be monitored and controlled. Furthermore, Dunning et al. (2002, p. 14) claim that one weakness of Armstrong's (1998) work is his failure to take into account sufficiently the special reality of Sheffield as a two-club city.

\section{METHODS}

This is an ethnographic study of the West Perth cheer squad 1984-1986 told from the viewpoint of the author who was co-founder and co-leader of this group alongside his school-friend Michael "Mike" Blewett. It is both strength and weakness of the research data that the author was an active participant in the events rather than a researcher performing typical ethnographic research as a non-participant. The author relies upon personal memories backed up by newspaper and book reports from the time; his personal 1984 season notes which were hand-written by him during 1984; and interviews and discussions with Mike Blewett conducted in person in Kalgoorlie, Australia on 14 July 2011 and since then by personal online communications. Other information about the era has been sourced from posts by supporters on the Facebook page Lost WAFL and the Facebook group Say NO to any AFL Clubs in the WAFL. The author applies Armstrong's anthropological approach to his 15-20 member West Perth unofficial cheer squad (hard-core supporter group) of 1984-1986.

\section{RESULTS}

Fluidity of group ties. Our West Perth cheer squad's experiences in Western Australia (19841986) definitely lend credence to Armstrong's 
(1998) theory about the casual nature of group ties and the fluidity of group membership with telephone calls between our members being rare; members knowing most other members only by first name and / or nickname; members usually not knowing where other members lived or if they did know they knew only the suburb name; members meeting only five times outside of football match days and only once outside of the football season (the cricket match referred to above); and the group withering and dying of its own accord, without any fanfare, over a few weeks early in the 1986 WAFL season. However, unlike some of the Blades members in Armstrong (1998), our group members did not adjust their commitment downwards during the cheer squad's years of action; most members attended all home-and-away matches during May 1984-March 1986.

As mentioned, the West Perth cheer squad had around 15 red-and-blue flags of various sizes, shapes, and designs, or around one flag per core member. The cheer squad also had a large $1.2 \mathrm{~m} \mathrm{x}$ $1.2 \mathrm{~m}$ red-and-blue banner with the words "Cop That" in white lettering, with the word "Cop" on the red horizontal section on top and the word "That" on the blue horizontal section making up the bottom half. The banner had thick wooden sticks on both sides and could be raised up above head-level at significant moments. We were very proud of that banner. It helped to give the cheer squad a tough and confrontational but still humorous image. According to my personal notes made during the 1984 season, this banner made its official debut at the Round 14 (7 July) 1984 match at Leederville Oval when West Perth defeated reigning premiers (i.e. champions) Swan Districts 18.11 (119) to $11.19(85)^{5}$.

Western Australia versus Victoria State of Origin game, Subiaco Oval, Tuesday afternoon 17 July 1984. I also took the "Cop That" banner with some school and neighbourhood mates, including Mike Blewett (the West Perth cheer squad's second co-founder), Paul Blewett, Chad S., Pete L., Roy G., Paul D., "Gilby", Wayne D., and Nick (not the Perth Football Club cheer squad leader) to the Western Australia (WA) versus Victoria State of Origin game held on Tuesday afternoon 17 July 1984. The group stood on the old concrete terraces (now long gone) on the Roberts Road side of Subiaco Oval in front of the old tin shed just in front of the entrance gates at the

5 Source: Match scores are taken from Atkinson (2008, p. 334). city-end. My personal 1984 season notes state that the West Perth cheer squad had been invited to join the combined Perth-Claremont cheer squad, which was representing WA that day in the grandstand, but the West Perth cheer squad declined. Instead I went to the game not with the cheer squad but with a school and neighbourhood-based group of friends. We all took the day off school, as did so many people for those well-attended Tuesday afternoon state games during the mid-eighties (annual games played on Tuesday afternoons from approximately 1983-1989), and we arrived at the game at $9.20 \mathrm{am}$. WA defeated Victoria 21.16 (142) to 12.12 (84) that day and, according to my 1984 season notes, the highlight of the match was Gary Ablett Senior kicking eight goals for the losing Victorian team.

Swan Districts versus West Perth, Bassendean Oval, 1985. A trip to Bassendean Oval to play Swan Districts requires a long train journey from the Perth city-centre on the ancient Midland train line. Swan Districts is the most remote from the city-centre of the six traditional WAFL clubs which are not Fremantle-based. (Fremantle is often regarded as a separate city in its own right.) By WAFL standards Bassendean is a fairly compact ground with the outer grassy banks being less wide and less high than those at East Fremantle Oval, Leederville Oval (prior to its recent renovations) or Lathlain Park. Like a soccer ground, all spectators are relatively close to the play. The famous old stands hug the playing arena closely and cast much of it in shadow in the late afternoons.

Since the formation of West Coast Eagles in 1987, "Swans" has had a reputation, fiercely and jealously guarded, of being the epitome of a traditional WAFL club. Bill Walker of Swan Districts was one of only two WAFL club presidents to vote against the entry of West Coast Eagles into the expanded VFL (now AFL). Even the once vibrant Midland and Guildford districts, at the centre of Swan Districts' geographic heartland, retain a large proportion of historic buildings and they seemed to have remained somewhat shielded from the economic, social, and demographic changes that the rest of Perth has experienced. Bassendean Oval used to be a fearsome place for visiting supporters; every corner of it was claimed by some gang or other of Swans' supporters. Even today, Swans attract larger home crowds than other WAFL clubs and the compact nature of the ground makes a crowd of two to three thousand mostly 
Swans' supporters still a fearsome proposition for opposition fans and players.

Although there was and is a members' stand, the R. A. McDonald Stand, in the ground's southwestern corner, has always contained vocal and hard-core Swan Districts' supporters of all ages. The stand still contains such dedicated supporters today, although nowadays there are empty seats during the main game. In the WAFL's Golden Era patrons had to arrive long before the start of the main game to be assured a seat in the McDonald Stand (pronounced as if it had an extra "s" as in "McDonald's Stand"). My late maternal grandfather H.A.A. (1906-1999) and his mate Ernie Henderson supported Swans and they always sat there, towards the top, in the seventies and into the first half of the eighties. I also sat with them there, on three or four occasions, although never when West Perth was the opponent.

On this most memorable day, most probably in 1985 , the West Perth cheer squad headed out to Bassendean Oval, from Perth city-centre on the Midland train line. I cannot recall how many people met in the city-centre beforehand. There was probably a sub-group which got on at the citycentre and the long journey then magnified our good spirits, self-confidence, and camaraderie. West Perth had been performing well on the field in 1985 and a win would certainly not have been an unlikely outcome. The cheer squad was in celebration and party mood, travelling to a distant and remote ground at the far end of the metropolitan area. Many cheer squad members would not have gone to the ground before.

No part of Bassendean Oval is seemingly reserved for the away supporters (except perhaps the Bill Walker Stand which is located to the immediate right of the McDonald Stand when viewed from inside the playing arena). The McDonald Stand is only 20 - or 30-metres from the southern-end goals. The northern-end goals ${ }^{6}$ are furthest from the train station so, logically, that was not the place for the away fans. The logic of the era was that visiting cheer squads (out of humility and respect) would stay near the entrance that was closest to the train station so that meant, for example, the southernend at Claremont Oval and the southern-end at Perth Oval.

6 The word "goals" is used in plural form in Australian Rules football culture because the goals are made up of four separate vertical posts.
I can recall our West Perth group this day entering what were then the most popular gates of the oval, in the south-west corner closest to Success Hill train station, with the giant flags. In the environment of Bassendean Oval, these flags stood out like a sore thumb. Swans' fans then had a dour and austere culture where you would not wear club colours. Anything slightly showy was frowned upon as not befitting this workingclass district far removed from the city-centre. Furthermore, Swans' colours are black-and-white; the cheer squad's red-and-blue replica playing jerseys and flags stood out like the first year of colour television. People probably thought that we were show-offs and smart-arses. We took the path of least resistance and set ourselves up behind the southern-end goals. The group's flags and banners were right there in front of the line of sight of the McDonald Stand's inhabitants around 25-metres away? ${ }^{7}$ The heritage-protected ground is largely unchanged today.

The cheer squad was chanting its usual chants that day but with perhaps unusual venom. There had been animosity between West Perth supporters and Swan Districts' manager John Todd since Todd left West Perth's Brian Adamson out of a Western Australian combined state team in 1975 (Dawson, 2004, pp. 148, 150). This animosity had then followed Todd across from East Fremantle to Swan Districts (ibid., p. 179). Dawson writes as follows about the relationship between Swans and West Perth during the 1980s: "The feud was always publicly denied, but continued into the 1980s and all Swans-West Perth games were wellattended with many fiery incidents, off and on the field" (ibid., p. 179). Swans' record home ground attendance remains today the 22,350 people who watched Swans play West Perth on 10 May 1980 (Round 6) (East, 2009, pp. 23, 212).

It may have been our "Ronnie Boucher walks on water / everybody knows that bullshit floats" chant that made the Swan Districts' fans increasingly upset on this particular day in 1985. Swan Districts had no recognized or organized cheer squad then but generally cheer squads accept each other's chants as just part of the job description and not to be taken seriously. The McDonald Stand was an intimidating place in that era and our cheer squad

7 The view of the McDonald Stand from the southern-end goals and the opposite view can be viewed at the following link: http://waflgoldenera.blogspot. co.uk/2017/02/opinion-presidents-response-to-todays. html [accessed 14 September 2017]. 
was insulting Swans' favourite players and showing off its vibrant red-and-blue colours directly in front of their noses. The cheer squad also had its famous song, sung to the tune of the classic children's song "Old McDonald had a Farm": "Old McDonald had a stand / eyie eyie oh / and in that stand was full of pigs / eyie eyie oh". The distant origins of the real Mr. R. A. McDonald ${ }^{8}$ meant that by 1985 our group clearly intended to insult a revered ancient folklore deity instead of an actual known person. The song was in effect an attack against local gods.

Around three-quarter time during the main game, we saw that a group of around eight barechested Aboriginal youths, around the group members' ages or slightly older, had very quietly surrounded us and taken up strategic seating positions just outside the group on all three sides. This Aboriginal group began to make intimidating comments including that they would beat up our group members after the game. The Aboriginal group members wore no club colours but they were very clearly Swans' supporters. They must have been offended by the West Perth flags and chanting. Our West Perth cheer squad watched the game much more diligently and stopped playing up to and taunting the inhabitants of the McDonald Stand. I could tell that our group members were apprehensive. Aboriginal gang culture and the culture of the suburbs around Bassendean Oval were not well known to any of the group. None of us had any reputation in the area that we could call on. It was the classic away fans scenario.

We all began to watch the game much more diligently and talk among ourselves; we adopted a much lower profile. We became just normal fans rather than a cheer squad as such. Even the noisiest members became quiet which was very remarkable. People became grossly absorbed in the match, looked straight ahead, and quietly conversed in their twos and threes. This was partly a strategic act and partly a sub-conscious switch to the self-preservation mode. The chanting mostly stopped although I am sure that we still waved the flags after West Perth goals.

8 The R.A. McDonald Stand was opened on 23 July 1938 , four years after the club was admitted to the WAFL (East, 2009, pp. 21, 87). R.A. (Dick) McDonald was President in the early years of the Swans club and played an important role in the then second-division club gaining WAFL admission in 1934 when he was acting in his capacity of member of the Bassendean Road Board (ibid., pp. 12-16, 20, 191).
When the game ended, or possibly five or ten minutes prior to that, the West Perth cheer squad members looked around and we saw that the Aboriginal group had disappeared. I do not think that anyone even saw or heard its members leave as they disappeared so quietly.

This Swan Districts versus West Perth match was probably either the 19.14 (128) to 15.12 (102) Swans' victory on 8 April 1985 (attendance 10,500) or the 22.12 (144) to 21.16 (142) Swans' victory on 20 July 1985 (attendance 9,462) 9 .

\section{DISCUSSION}

Fluidity of group ties. When I stopped going to games during 1986, no-one ever contacted me (and I had been co-founder and co-leader) and when I met ex-member Pete C. at Fremantle Oval at a game against South Fremantle late in the 1986 home-and-away season we conversed only as friends and neither of us made any mention (if my memory serves me correctly) of the end of the cheer squad. There was only the two of us; we met by chance rather than by arrangement; and the flags and banners were long gone. We probably avoided discussing the cheer squad's end as it might have been a sad topic. Possibly people could sense my and key others' new-found lack of enthusiasm for the cheer squad in 1986 and the infectious zeal that had held the group together for two years simply saw its opposite occur: people drifted away because the igniting zeal had left. Only the zeal for West Perth and for the cheer squad had kept the cheer squad together for two full years and through two complete summer off-seasons (which are six months long in Perth). I admit that my new preoccupation during 1986 was my university studies. In hindsight I wish that I had been slightly more pro-active in extending the life of the cheer squad without feigning interest or departing from the group's original authenticity.

Western Australia versus Victoria State of Origin game, Subiaco Oval, Tuesday afternoon 17 July 1984. Mike B. and I decided that, because the game took place on a school-day, our ethical obligation towards our school friends exceeded our ethical obligation to go with cheer squad members and / or to join the combined Perth-Claremont cheer squad representing WA that day. This was the choice we made based upon our ethical values.

9 Source: Match scores are taken from Atkinson (2008, pp. 334, 335). 
We could plan together at school on the Monday with school friends for the next day and we felt that we should attend the game with them on the Tuesday. We all took the day off school, as did so many people for those well-attended Tuesday afternoon state games during the mid-eighties.

Swan Districtsversus West Perth, Bassendean Oval, 1985. If we want some theorization of the West Perth cheer squad members' behavioural self-modifications after being threatened by the Aboriginal group of Swan Districts fans, we might cite Marsh (1978, pp. 19, 41) as follows:

"we can instantly recognize dominant or submissive stances in other people and we frequently employ them ourselves ... Adopting a submissive posture is the clearest way in which ... a person ... can signal that he has had enough and thus avoid serious injury".

When the game ended, or possibly five or ten minutes prior to that, the West Perth cheer squad looked around and we saw that the Aboriginal group had disappeared. Our West Perth group had passed some kind of test. Possibly the Swan Districts' group had decided that we were "good guys at heart" or possibly they had just lost interest in confrontation or had somewhere to go straight after the match. Swans' on-field victory that day might possibly have been seen by the Aboriginal group as having been vindication enough for them (as Mike B. today claims ${ }^{10}$ ).

Like the London Teddy Boys who menacingly surrounded Desmond Morris and his wife in a Camden Town cafe in 1957 but then paid the couple's bill and left with a friendly greeting (Morris, 1978, p. 7), the Swan Districts group had reinforced territorial dominance by Swans' fans over Bassendean Oval, including the seats behind the southern-end goals, without resorting to actual violence. Marsh (1978, p. 125) explains further as follows: "When men enter into aggressive confrontations with each other, the object of the exercise is not killing but preservation of dominance relations, the defence of particular space or access to basic resources".

This event at Bassendean Oval's southern-end goals was a near-miss for the West Perth cheer squad and our group members probably learned a lesson to be somewhat quieter, more respectful, and more circumspect in hostile away territory. It must be pointed out that the cheer squad members

10 Source: Personal interview with the author, Kalgoorlie, 14 July 2011. never viewed this encounter as any sort of "racial war" - our group was multicultural and had a multicultural ethos. For example, D.S. from Tuart Hill was an ethnic Chinese and the brothers Tony and Mario were of Italian ethnicity. In fact West Perth supporters have long been referred to by the racist tag of "Garlic Munchers" (especially by East Perth fans). This tag emerged because of the large southern-European immigrant supporter base which attached itself to the club in the post-World War II period.

About the near-miss at Bassendean Oval, on reflection, I can say that our group had probably had become a little over-confident. Our cheer squad went to Bassendean Oval thinking that, because there was no organized Swan Districts' cheer squad, we could pretty much express ourselves as we liked as far as flag-waving and noise-making were concerned. Being far from home created a carnival or a day-at-the-seaside atmosphere for our group members. The hostility between the two clubs was a factor in the background which was probably driving us on to chant a little louder. I probably did not "rate" the Aboriginal group when I first saw it as it was not a Melbourne-style cheer squad and its guys were shirtless and not wearing club colours. Why was this day memorable aside from just the physical threat? Perhaps because different concepts of fandom, match-day behaviours, and dress codes were operating and these concepts clashed. I respected and tried to keep cordial relationships with the Perth and Claremont cheer squads but I did not perceive any necessity to have a similar fraternal and respectful attitude with respect to any or all Swan Districts' fans (even though my grandfather supported the club).

\section{CONCLUSIONS}

General conclusions. In this article I have reviewed key studies in the academic literature on football hooliganism. I have applied the anthropological approach to our 15-20 member West Perth cheer squad of 1984-1986. I find that Armstrong's anthropological approach is able to explain many aspects of our cheer squad's culture and members' behaviours including the quick disintegration of the cheer squad early in the 1986 season without anyone officially putting an end to it. However, our group members did not adjust their commitment downwards during the cheer squad's years of action; most members attended all home-and-away matches from May 1984-March 
1986. This research also shows the diffusion of Australian Rules football supporter culture from Melbourne to Adelaide and from these two cities to Perth, to a certain lesser extent, and the impact of TV news reports of British football hooliganism on our group's style and macho posturing.

Personal reflections. I would like to make some personal reflections both as a researcher and as cheer squad co-founder. As a researcher, I think it is important that we document supporter and cheer squad culture of Australian Rules football, and expose this research to an international audience. I think that, following Redhead (2017), detailed long-term ethnographic studies of individual football hooligan firms, ultras groups, and cheer squads are the most vital type of new research. Redhead (2017) notes that since the publication of Armstrong's book nearly 20 years ago there have been very few new detailed ethnographic studies similar to his prize-winning $\mathrm{PhD}$ thesis and book. A problematic topic, also covered well by Redhead (2017), is to what extent we should bring into academic discourses the confessions memoirs of ex-hooligans, referred to sometimes as hooliporn or, in Redhead's words, the "hit and tell" genre. Although obviously not every fact in such books can be taken as being accurate or every recollection truthful or every expression of regret sincere, they may be useful for filling in gaps in our knowledge especially for firms and cities not (yet) covered by academic ethnographic researchers (ibid).

As a cheer squad co-founder I can say that the days of the cheer squad were among the happiest times of my teenage years; and it was a good experience for me in the areas of leadership, people-management, organizational skills, and public-relations relating to such a diverse group of people from a wide variety of social backgrounds and aged from 8 to 18. I do regret some of our insulting chants; especially "Benny's got a Vigona" aimed at South Fremantle's star Aboriginal player Benny Vigona. Although not chanted with any racist intent (at least not by me), I conclude that Aboriginal players do not need to be exposed to unnecessary toilet humour, if it can be called humour, from the spectators' side of the fence.

\section{POSTSCRIPT}

Our cheer squad's "Cop That" banner was captured on camera at the Western Australia versus Victoria match played at Subiaco Oval on
17 July 1984. The banner was later used in an Emu Export beer commercial which ran for many years, and long after our West Perth cheer squad had disbanded. For me the sighting of the banner on the beer commercial was one of the last tangible reminders of the then defunct West Perth cheer squad of 1984-86. I remember reading about the graffiti tag "The Clash", located on the Harrow Road in West London at the place where it passes under the Westway. Similarly to our banner on the beer commercial, the graffiti remained there, fading slowly, long after that punk-rock group's vigorous life was over.

Acknowledgements. I would like to thank Brian Atkinson, Michael Blewett, John Devaney, Chris Egan, Lionel Frost, Sean Gorman, Chris Hallinan, and Roy Hay for encouragement and information provided during the course of the research process. This research had zero funding from external sources.

Dedication. This article is dedicated to my late maternal grandfather H.A.A. (1906-1999).

Disclaimer. The opinions expressed herein are not necessarily the same as those of Brian Atkinson; West Perth Football Club (WPFC); West Perth Football Club cheer squad 1984-86 or any of its members; Swan Districts Football Club (SDFC); Australian Football League (AFL); West Coast Eagles Football Club (WCEFC); Western Australian Football Commission (WAFC); Western Australian Football League (WAFL); and / or any of the study's interviewees.

\section{APPENDIX}

\section{Sub-gangs, West Perth Cheer Squad, 1984-86 (ages as at 1984) \\ The Booragoon sub-gang}

1 *The author, 15 years, Applecross Senior High School student (1984-85) then university student (1986)

2 *Mike Blewett, 16 years, Applecross Senior High School (1984-85) then occupation unknown (1986), school friend of the author

\section{The Carine sub-gang}

3 Courtney, 14 years, high-school student, junior football friend of Thommo.

4 Rohan H., 14 years, high-school student, school friend of Courtney.

\section{Floaters / non-aligned}

5 *Mark aka "Thommo", 14 years, high-school student (1984-85), plasterer (1986); junior football friend of Courtney. 
6 *Robbie, 14 years, joined cheer squad 1985, lived in Balga, took buses home with Balga subgang, knew Thommo before joining cheer squad.

\section{The Balga sub-gang}

7 *Peter "P.A." Brennan (name changed), 18 years, lived in Balga.

8 *Dave S. (name changed), 16 years, lived in nearby Tuart Hill but took buses to games with P.A. and Robbie, school / employment situation unknown.

\section{The $\mathbf{C}$. brothers sub-gang}

9 *Mike C., 16 years, in and out of reform homes.

$10 *$ Robert C., 15 years, only went to games occasionally, had criminal record.

11 *Pete C., 14 years, in and out of reform homes.
12 *Female niece or cousin of the C. brothers, 4 years, attended $50 \%$ of games..

\section{The Churchlands sub-gang}

13 Ben McA., 14 years, Churchlands Senior High School student.

14 Tony, 12-13 years, Churchlands student, school friend of Ben.

15 Mario, 8-9 years, younger brother of Tony (also in younger members' sub-gang).

\section{The younger members sub-gang}

16 Michael aka "Half", 8 years, parents were financial members of West Perth, no blood relationship to other cheer squad members, lived in Bayswater or Maylands.

17 *"Thommo Junior", 8 years, younger brother of Thommo.

(* denotes took public transport to and from games).

\section{REFERENCES}

Allan, J. (1989). Bloody casuals: Diary of a football hooligan. Elton: Famedram Publishers.

Althusser, L. (2001) [1971]. Ideology and ideological state apparatuses. In L. Althusser (Ed.), Lenin and philosophy and other essays. New York, NY: Monthly Review Press [originally published 1971].

Armstrong, G. (1998). Football hooligans: Knowing the score (explorations in anthropology), paperback edition. Oxford: Berg.

Armstrong, G., \& Harris, R. (1991). Football hooligans: Theory and evidence. The Sociological Review, 39(3), 427-458

Atkinson, B. A. (2008). It's a grand old flag: A history and comprehensive statistical analysis of the West Perth Football Club. Joondalup: West Perth Football Club.

Bennett, J. G. (2009). E.1: Ajourney through Whitechapel and Spitalfields. Nottingham: Five Leaves Publications.

Bestley, R. (2011). From 'London's Burning' to 'Sten Guns in Sunderland'. Punk \& Post Punk, 1(1), 41-71.

Critchley, C. (2010). Our footy: Real fans vs big bucks. Melbourne: Wilkinson Publishing.

Dawson, B. (2004). John Todd: Six decades of footy. West Leederville: Cambridge Publishing.

Devaney, J. (n.d.). East Fremantle Football Club bio. Retrieved from http://australianfootball.com/clubs/bio/ East $\% 20$ Fremantle/96

Duke, V., \& Crolley, L. (1996). Football, nationality and the state. London: Longman.

Duke, V., \& Slepička, P. (2002). Bohemian rhapsody: Football supporters in the Czech Republic. In E. Dunning, P. Murphy, I. Waddington, \& A. E. Astrinakis (Eds.), Fighting fans: Football hooliganism as a world phenomenon. Dublin: University College Press.
Dunning, E., Murphy, P., \& Waddington, I. (1991) Anthropological versus sociological approaches to the study of soccer hooliganism: Some critical notes. The Sociological Review, 39(3), 459-478.

Dunning, E., Murphy, P., \& Waddington, I.(2002). Towards a sociological understanding of football hooliganism as a world phenomenon. In E. Dunning, P. Murphy, I. Waddington, \& A. E. Astrinakis (Eds.), Fighting fans: Football hooliganism as a world phenomenon (pp. 1-22). Dublin: University College Press).

Dunning, E. (1999). Sport matters: Sociological studies of sport, violence and civilisation. London and New York, NY: Routledge.

East, A. (2009). 75 years of ... black \& white, the Swan Districts Football Club West Australian Football League 1934-2008. Perth: Swan Districts Football Club.

Gardner, B. (2006). Good afternoon gentlemen, the name's Bill Gardner, with C. Pennant. London: John Blake Publishing.

Hughson, J. (1999). A tale of two tribes: Expressive fandom in Australian soccer's A-league. Culture, Sport, Society, 2(3), 10-30.

Hughson, J. (2002). Australian soccer's 'ethnic tribes': A new case for the carnivalesque. In E. Dunning, P. Murphy, I. Waddington, \& A. E. Astrinakis (Eds.), Fighting fans: Football hooliganism as a world phenomenon. Dublin: University College Press.

Hughson, J. (1997b). The Bad Blue Boys and the 'magical recovery' of John Clarke. In G. Armstrong and R. Giulianotti (Eds.), Entering the field: New perspectives on world football (Chapter 12, pp. 239259). London and New York, NY: Berg.

Hughson, J. (2000). The boys are back in town: Soccer support and the social reproduction of masculinity. Journal of Sport and Social Issues, 24(1), 8-23. 
Hughson, J. (1997a). Football, folk dancing and fascism: Diversity and difference in multicultural Australia. Australian \& New Zealand Journal of Sociology, 33(2), 167-186.

James, K., \& Walsh, R. (2017). The expropriation of goodwill and migrant labour in the transition to Australian football's A-League. International Journal of Sport Management and Marketing [published online]. Lynch, R. L., \& Veal, A. J. (1996). Australian Leisure. South Melbourne: Longman.

Marsh, P. (1978). Aggro: The illusion of violence, hardcover edition. London: J. M. Dent \& Sons.

Morris, D. (1978) Foreword. In P. Marsh (Ed.), Aggro: the illusion of violence, hardcover edition (pp. 7-8) London: J. M. Dent \& Sons.

Muyt, A. (2006). Maroon \& blue: Recollections and tales of the Fitzroy Football Club. Carlton North: The Vulgar Press.

Panfichi,A., \& Thieroldt, J. (2002). Barras bravas: Representation and crowd violence in Peruvian football. In E. Dunning, P. Murphy, I. Waddington, \& A. E. Astrinakis (Eds.),
Fighting fans: Football hooliganism as a world phenomenon. Dublin: University College Press.

Pennant, C. (2003). Congratulations, you have just met the I.C.F. (West Ham United). London: John Blake Publishing.

Pennant, C., \& Silvester, R. (2004). Rolling with the 6.57 crew: The true story of Pompey's legendary football fans, paperback edition (London: John Blake Publishing).

Redhead, S. (2017). Football and accelerated culture: This modern sporting life, paperback edition. Abingdon and New York, NY: Routledge.

Roversi, A., \& Balestri, C. (2002). Italian ultras today: Change or decline? In E. Dunning, P. Murphy, I. Waddington, \& A. E. Astrinakis (Eds.), Fighting fans: Football hooliganism as a world phenomenon (pp. 131142). Dublin: University College Press).

Savage, J. (2005). England's dreaming: Sex Pistols and punk rock. London: Faber and Faber.

Young, K. (2002). A walk on the wild side: Exposing North American sports crowd disorder. In E. Dunning, P. Murphy, I. Waddington, \& A. E. Astrinakis (Eds.), Fighting fans: Football hooliganism as a world phenomenon (pp. 201-217). Dublin: University College Press).
Corresponding author Kieran James School of Business and Enterprise University of the West of Scotland Paisley campus

Paisley

Renfrewshire, Scotland, PA1 2BE Tel. +44 (0)141-848-3350

E-mail Kieran.James@uws.ac.uk

Kieran.james99@yahoo.co.uk 